\title{
PENGARUH KUALITAS LAYANAN TERHADAP LOYALITAS NASABAH TABUNGAN BANK SYARIAH DI KABUPATEN JOMBANG YANG DIMEDIASI VARIABEL KEPUASAN
}

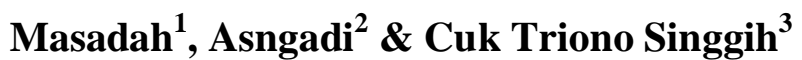 \\ ${ }^{1}$ Sekolah Tinggi Ilmu Ekonomi (STIE) KH. Ahmad Dahlan Lamongan \\ ${ }^{2}$ Universitas Tadulako \\ ${ }^{3}$ Sekolah Tinggi Ilmu Ekonomi (STIE) KH. Ahmad Dahlan Lamongan \\ Email :masadah1977@gmail.com
}

\begin{abstract}
ABSTRAK
Tujuan dari penelitian ini adalah menguji secara empiris indikator yang menunjukkan variabel paling dominan diantara kualitas pelayanan, kepuasan pelanggan, dan loyalitas. Selain itu juga untuk menjelaskan pengaruh dari kualitas layanan yang terdiri dari kepuasan pelanggan, dan loyalitas dan pengaruh kualitas pelayanan terhadap loyalitas yang dimediasi kepuasan pelanggan. Penelitian ini menggunakan pendekatan kuantitatif positivisme, populasi penelitian ini adalah 150 nasabah bank syariah yang ada di Kabupaten Jombang dengan menggunakan proportional random sampling. Teknik dari analisis data menggunakan deskriptif dan alat analisis inferensial SEM. Hasil dari penelitian ini menunjukkan bahwa suasana persaingan yang dihadapi oleh bank syariah menuntut untuk melakukan perombakan pada bisnisnya dengan memperhatikan bahwa kualitas pelayanan memiliki pengaruh yang positif dan signifikan terhadap kepuasan pelanggan dan loyalitas. Kepuasan pelanggan memiliki pengaruh yang positif dan signifikan terhadap loyalitas pelanggan bank syariah di Kabupaten Jombang.
\end{abstract}

Kata kunci : Kualitas Pelayanan, Kepuasan, Loyalitas, Bank Syariah.

\begin{abstract}
The purpose of this study is to empirically test the indicators that show the most dominant variables among service quality, customer satisfaction, and loyalty. In addition, it is also to explain the effect of service quality which consists of customer satisfaction, and loyalty and the influence of service quality on loyalty mediated by customer satisfaction. This study uses a positivist quantitative approach, the population of this study is 150 customers of Islamic banks in Jombang district using proportional random sampling. Techniques of data analysis using descriptive and inferential analysis tools SEM. The results of this study indicate that the competitive atmosphere faced by Islamic banks demands to reform their business by taking into account that service quality has a positive and significant impact on customer satisfaction and loyalty. Customer satisfaction has a positive and significant effect on customer loyalty of Islamic banks in Jombang district.
\end{abstract}

Keywords : Service Quality, Satisfaction, Loyalty, Islamic Bank. 


\section{PENDAHULUAN}

Pemasaran pada hakikatnya merupakan kegiatan yang bertujuan untuk membentuk dan mempertahankan pelanggan yang memberikan keuntungan bagi perusahaan, selain itu pemasaran dilakukan untuk menciptakan pelanggan. Pelanggan merupakan faktor penting yang harus diperhatikan oleh perusahaan karena pelanggan merupakan aset yang dapat menentukan keberhasilan perusahaan. Pelanggan akan merasa puas dan loyal kepada perusahaan jika perusahaan memberikan kualitas layanan yang maksimal. Pelanggan yang tidak puas dengan produk atau jasa yang diterima, dengan membandingkan kualitas yang diharapkan berdasarkan informasi yang diterima sebelum membeli suatu produk sehingga pelanggan akan membuat tanggapan berupa keluhan atau saran untuk perbaikan. Keluhan pelanggan telah disampaikan secara lisan, melalui telepon atau kunjungan langsung ke perusahaan, dan secara tertulis melalui surat, SMS, atau bentuk kuesioner yang disebarkan. Perusahaan harus bertindak cepat dalam merespon semua keluhan yang disampaikan oleh pelanggan untuk menciptakan kualitas layanan yang maksimal. (Dewi, 2016)

Penelitian sebelumnya menyatakan bahwa kualitas layanan berpengaruh terhadap loyalitas pelanggan. (Khan \& Fasih, 2014., Leninkumar, 2017., Ngo \& Nguyen, 2016., Siddiqi, 2011., Tumbuan et al., 2014). Manajemen perusahaan perlu menekankan pada program kepuasan pelanggan melalui strategi yang berpusat pada kualitas layanan untuk mendapatkan pelanggan yang loyal kepada perusahaan di beberapa industri jasa perbankan Islam selama lebih dari dua puluh tahun telah berhasil mengembangkan dasar teori dari sistem ekonomi Islam. Banyak hal yang telah dilakukan berkaitan dengan kepentingan ini pada sebagian besar negara muslim. Sistem ekonomi Islam dan penerapannya baik di tingkat nasional maupun internasional didasarkan pada apa yang tertulis dalam Al- Qur'an. Terdapat pula asumsi bahwa tidak semua negara saat ini atau nantinya, siap untuk mengganti sistem ekonomi Islam secara total. Sistem ekonomi Islam yang ideal saat ini hanya ada dalam pemikiran kelompok perguruan tinggi atau bersifat teori, sehingga perlu disosialisasikan tentang sistem ekonomi Islam yang ideal kepada masyarakat muslim. (Syukron, 2013)

Masyarakat Indonesia sebagian besar adalah muslim, oleh karenanya potensi pasar perbankan syariah di Indonesia mengalami perkembangan yang cukup pesat dan signifikan. Ditandai dengan banyak berdirinya Badan Perkreditan Rakyat Syariah (BPRS), dan banyak bank-bank konvensional yang membuka kantor cabang bank syariah, bahkan mengganti jenis usahanya, dari bank konvensional menjadi bank syariah. Kinerja ini semakin nyata ketika badai krisis melanda Indonesia (Abubakar \& Handayani, 2018)

Pada saat perbankan konvensional banyak yang terpuruk, perbankan syariah relatif dapat bertahan, bahkan menunjukkan perkembangan, sejalan dengan bertambahnya jumlah bank syariah yang beroperasi, jaringan kantor bank syariah juga mengalami perkembangan yang signifikan sebesar 2244 kantor pada tahun 2019, menjadi 2308 kantor pada tahun 2020. Penyebaran jaringan kantor bank syariah, saat ini telah menjangkau 89 Kabupaten/Kota di 33 Propinsi di seluruh Indonesia. Posisi jumlah jaringan kantor secara rinci dapat di lihat pada tabel di bawah ini : 
Tabel 1. Jaringan Kantor Bank Umum Syariah dan Unit Usaha Syariah

\begin{tabular}{lrrrr}
\hline \multicolumn{1}{c}{ Keterangan } & \multicolumn{1}{c}{2017} & \multicolumn{1}{c}{2018} & 2019 & \multicolumn{1}{c}{2020} \\
\hline Bank Umum Syariah & 1.825 & 1.875 & 1.885 & 1.922 \\
Unit Usaha Syariah & 334 & 354 & 359 & 386 \\
\hline Total Jumlah Kantor & 2159 & 2229 & 2244 & 2308 \\
\hline & Sumber : OJK (2020) & &
\end{tabular}

Perbankan syariah yang bergerak di bidang jasa dan pelayanan, dituntut untuk terus melakukan perbaikan dalam memberikan pelayanan terbaik pada nasabah. Perbankan syariah harus memberikan pelayanan yang personalized dan profesional, sehingga kepuasan oleh nasabah dapat terbangun hal ini diperlukan agar dapat bersaing dengan perbankan konvensional. (Atmaja, 2018., Sigit \& Soliha, 2017., Yaqin \& Ilfitriah, 2015).

Loyalitas nasabah ditentukan oleh kegunaan dari barang atau jasa yang dikehendaki dan diharapkan nasabah, sehingga jaminan kualitas dan nilai menjadi prioritas. Nasabah akan merasa loyal jika kualitas pelayanan yang diberikan oleh perbankan syariah dilakukan dengan baik sehingga memunculkan rasa kepuasan yang tinggi (Burhanudin, 2018).

Menurut penelitian (Sutisna, 2016) loyalitas diartikan sebagai suatu perilaku yang diharapkan atas suatu produk atau layanan yang antara lain meliputi kemungkinan pembelian lebih lanjut atau perubahan perjanjian pelayanan atau sebaliknya seberapa besar kemungkinan pelanggan akan beralih kepada merek atau penyedia layanan lain. Loyalitas dapat terbentuk apabila pelanggan merasa puas dengan merek atau tingkat layanan yang diterima dan berniat untuk terus melanjutkan hubungan. Pelanggan dapat menjadi loyal karena adanya hambatan peralihan yang besar dengan faktor teknis, ekonomi atau psikologis yang dirasakan mahal atau sulit untuk beralih kepada penyedia layanan yang lain. Untuk mengatasi persaingan, bank syariah dituntut untuk tampil dengan peningkatan kualitas layanan yang baik, prinsip keadilan dalam bagi hasil dan inovatif sehingga memiliki rasa loyalitas yang tinggi. Hal ini yang akan menjadi titik tolak dalam penelitian ini.

Objek penelitian adalah nasabah tiga bank syariah (BNI Syariah, BRI Syariah dana BSM) di Kabupaten Jombang. Jombang dengan ikon "Kota Santri" menjadikan daya magnet para pemuda untuk menimba ilmu di pondok pesantren.dan para usaha bisnis termasuk jasa perbankan keuangan syariah untuk membuka jaringan kantornya. Jombang sebagai kota santri dengan penyebaran pondok pesantren sangatlah relevan jika dihubungkan dengan keberadaan bank syariah.

\section{TINJAUAN PUSTAKA}

\section{Kualitas Layanan}

Pengertian kualitas layanan dimulai dari pengertian istilah kualitas yang diartikan dari "zero defect", artinya melakukan dengan benar untuk pertama kali (Parasuraman et al., 1985). Kualitas juga berarti "kesesuaian dengan persyaratan". Kualitas diukur dengan menghitung kegagalan internal seperti aktivitas bisnis sebelum produk dijual, dan kegagalan eksternal seperti aktivitas bisnis setelah produk terjual.

Menurut Parasuraman et al., (1985) mendefinisikan bahwa kualitas layanan mengandung tiga pemahaman mendasar yang harus diakui untuk semua pemahaman tentang kualitas layanan, yang disebut dengan tiga karakteristik layanan yang terdokumentasi dengan baik, yaitu: intangibility, heterogeneity, dan 
inseparability. Pertama, karakteristik layanan adalah intangibility, ini berarti bahwa sebagian besar layanan tidak berwujud karena layanan adalah kinerja daripada objek. Layanan tidak dapat dihitung, diukur, diinventarisasi, diuji, dan diverifikasi sebelum penjualan untuk memastikan kualitas. Kedua, karakteristik layanan adalah heterogenitas, Artinya pelayanan bersifat heterogen, kinerja pelayanan seringkali bervariasi dalam kegiatan bisnis. Ketiga, karakteristik layanan tidak dapat dipisahkan, ini berarti bahwa produksi dan konsumsi banyak layanan tidak dapat dipisahkan.

Variabel kualitas layanan (SERVQUAL) terdiri dari lima dimensi (Parasuraman et al., 1988). Dimensi jaminan dan empati adalah item dari tujuh dimensi asli yang terdiri dari komunikasi, kredibilitas, keamanan, kompetensi, kesopanan, pemahaman/mengetahui pelanggan, dan akses; yang tidak tetap berbeda setelah dua tahap pemurnian skala (Parasuraman et al., 1985). Dalam teori perkembangan selanjutnya, kualitas layanan hanya memiliki lima dimensi, yaitu (1) Tangibles: bukti fisik dari layanan, seperti fasilitas fisik, peralatan, dan kinerja karyawan; (2) Empati: kepedulian, perhatian perusahaan terhadap pelanggannya; (3) Reliabilitas: kemampuan untuk melakukan layanan yang dijanjikan secara andal dan akurat; (4) Responsiveness: kesediaan untuk membantu pelanggan dalam memberikan pelayanan yang dibutuhkan; dan (5) Assurance: kemampuan perusahaan untuk memberikan jaminan layanan purna jual kepada pelanggan.

Dimensi kualitas pelayanan yang dianalisis di bank syariah Kabupaten Jombang adalah: (1) Bukti fisik/fisik, terdiri dari indikator kelengkapan alat pelayanan, penampilan pegawai dalam tugas, fasilitas kantor dalam pelayanan produk yang dibutuhkan oleh pelanggan, dan kondisi ruang kantor; (2) Empati, terdiri dari indikator seperti karyawan memahami kebutuhan pelanggan dan sikap ramah karyawan kepada pelanggan; (3) Reliabilitas, terdiri dari indikatorindikator seperti kecepatan dalam melayani pelanggan di teller dan ketepatan dalam memberikan layanan s; (4) Responsiveness, terdiri dari indikatorindikator seperti sikap kooperatif karyawan dalam merespon terhadap keluhan pelanggan dan karyawan memberikan respon cepat dalam menindaklanjuti keluhan pelanggan; dan (5) Assurance, terdiri dari indikator seperti keamanan pelanggan saat melakukan transasksi perbankan dan ketersediaan tempat parkir kendaraan pelanggan.

\section{Kepuasan Pelanggan}

Sejumlah ahli memberikan definisi mengenai kepuasan pelanggan. (Kotler, 2012) mendefinisikan kepuasan pelanggan sebagai perasaan suka atau tidak suka seseorang terhadap suatu produk setelah membandingkan kinerja produk tersebut dengan yang diharapkan. Sementara (Johnson et al., 2014) menyatakan bahwa kepuasan konsumen merupakan hasil evaluasi menyeluruh konsumen atas kinerja produk yang dikonsumsinya. (Moha \& Loindong, 2016), mengatakan bahwa kepuasan merupakan faktor yang berpengaruh langsung terhadap loyalitas.

\section{Loyalitas Pelanggan}

Istilah loyalitas pelanggan identik dengan strategi perusahaan untuk bertahan dalam persaingan bisnis. Loyalitas atau loyalitas pelanggan sangat erat kaitannya dengan kepuasan pelanggan karena pelanggan merasa puas dengan pembelian suatu produk atau jasa, maka pelanggan akan loyal untuk membeli kembali suatu produk perusahaan (Holbrook, 2012). Loyalitas digambarkan sebagai komitmen yang dipegang teguh untuk membeli kembali atau melindungi kembali produk/layanan yang disukai secara konsisten di masa depan, sehingga 
menyebabkan merek berulang yang sama atau pembelian set merek yang sama, meskipun pengaruh situasional dan upaya pemasaran berpotensi menyebabkan peralihan perilaku. Istilah loyalitas pelanggan diartikan sebagai komitmen yang dipegang oleh pelanggan untuk membeli kembali suatu produk atau layanan secara konsisten di masa depan, yang mengarah pada pembelian kembali merek yang sama. (Holbrook, 2012; Oliver, 1997) Menyatakan bahwa konsumen dapat menjadi "loyal" pada setiap fase sikap yang berkaitan dengan berbagai elemen struktur pengembangan sikap. Pelanggan akan menjadi loyal dalam arti kognitif, kemudian dalam arti afektif, kemudian masih secara konatif, dan terakhir dalam perilaku yang disebut sebagai "Tindakan Inersia." Konsep loyalitas pelanggan terdiri dari loyalitas kognitif, loyalitas afektif, loyalitas konatif, dan loyalitas tindakan. Loyalitas kognitif berkaitan dengan informasi berbasis pengalaman pelanggan. Loyalitas afektif berkaitan dengan pengembangan loyalitas yang mencerminkan dimensi kesenangan dari definisi kepuasan yaitu pemenuhan yang menyenangkan. Loyalitas konatif berkaitan dengan komitmen pelanggan untuk membeli kembali produk perusahaan. Loyalitas pelanggan yang terakhir adalah loyalitas tindakan, yaitu pengendalian tindakan pelanggan, yaitu keadaan loyalitas yang ditransformasikan menjadi kesiapan pelanggan untuk melakukan rekondisi produk perusahaan secara berulang.

Dimensi loyalitas pelanggan terdiri dari sikap dan perilaku pelanggan (Semuel, 2012). Komponen sikap pelanggan mewakili gagasan seperti niat membeli kembali atau membeli produk atau layanan tambahan dari perusahaan yang sama, kesediaan untuk merekomendasikan perusahaan kepada orang lain, menunjukkan komitmen tersebut kepada perusahaan dengan menunjukkan penolakan untuk beralih ke pesaing lain, dan kesediaan untuk membayar harga premium. Aspek perilaku pelanggan merepresentasikan actual pembelian berulang produk atau layanan yang mencakup pembelian produk atau layanan yang lebih banyak dan berbeda dari perusahaan yang sama, merekomendasikan perusahaan kepada orang lain, dan mencerminkan probabilitas pilihan jangka panjang untuk merek tersebut. Tipologi perilaku pelanggan terutama berkaitan dengan ukuran atau pembelian berulang dan proporsi pembelian. Tipologi ini tidak mencakup motif pelanggan atas perilaku mereka, meskipun ini dianggap sebagai ukuran yang relevan.

\section{METODE PENELITIAN}

\section{Rancangan Penelitian}

Penelitian ini adalah penelitian kuantitatif untuk melihat hubungan antara dua variabel atau lebih dengan pengujian hipotesis melalui pengukuran variabel dengan instrumen yang dikuantifisir dengan skala likert. Pengujian hipotesis selain untuk membuktikan pengaruh suatu variabel terhadap variabel lainnya, juga dimaksudkan untuk melihat besarnya pengaruh hubungan tersebut. Populasi dan Sampel Populasi penelitian ini adalah seluruh nasabah yang menyimpan dananya di bank syariah di Kabupaten Jombang dalam bentuk tabungan. Teknik penarikan sampel dengan metode proporsional random sampling yang diambil dari 3 bank syariah yaitu BNI Syariah, Bank Syariah Mandiri dan BRI Syariah.

\section{Definisi Operasional Variabel}

Dalam penelitian ini terdapat tiga jenis variabel yaitu variabel independen, variabel dependen dan variabel intervening. Variabel independen terdiri dari kualitas pelayanan, sedangkan variabel dependen adalah loyalitas 
nasabah, dan variabel intervening adalah kepuasan nasabah.

Teknik Pengumpulan Data Pengumpulan data primer dilakukan dengan kuesioner yang diberikan kepada responden. Pengukuran jawaban atas kuesioner menggunakan skala Likert $1 \mathrm{~s} / \mathrm{d}$
5 , dimana $1=$ sangat tidak setuju, $2=$ tidak setuju, $3=$ netral, $4=$ setuju dan $5=$ sangat setuju. Sedangkan data sekunder dengan memperoleh data dari bank syariah dan sejumlah literatur buku dan internet.

\section{Tabel 2 : Definisi Operasional Variabel}

\begin{tabular}{|c|c|c|c|}
\hline No & Variabel & Definisi Variabel & Indikator \\
\hline 1 & $\begin{array}{l}\text { Kualitas } \\
\text { Layanan }\end{array}$ & $\begin{array}{l}\text { Kualitas pelayanan adalah tingkat keunggulan } \\
\text { yang diharapkan dan pengendalian atas } \\
\text { tingkat keunggulan tersebut untuk memenuhi } \\
\text { keinginan nasabah Bank Syariah di } \\
\text { Kabupaten Jombang (Tjiptono \& Chandra, } \\
\text { 2011) }\end{array}$ & $\begin{array}{l}\text { Tangible } \\
\text { Responsiveness } \\
\text { Assurance } \\
\text { Reliability } \\
\text { Emphaty }\end{array}$ \\
\hline 2 & $\begin{array}{l}\text { Kepuasan } \\
\text { Nasabah }\end{array}$ & $\begin{array}{l}\text { Kepuasan nasabah Bank Syariah di } \\
\text { Kabupaten Jombang sebagai perasaan suka } \\
\text { atau tidak suka terhadap produk tabungan } \\
\text { Bank Syariah setelah membandingkan kinerja } \\
\text { produk tersebut dengan yang diharapkan. } \\
\text { (Kotler, 2012). }\end{array}$ & $\begin{array}{l}\text { Pengalaman } \\
\text { Harapan } \\
\text { Kepuasan } \\
\text { menyeluruh }\end{array}$ \\
\hline 3 & $\begin{array}{l}\text { Loyalitas } \\
\text { Nasabah }\end{array}$ & $\begin{array}{l}\text { Kesetiaan nasabah untuk tetap menggunakan } \\
\text { tabungan Bank Syariah secara berulang- } \\
\text { ulang. (Indah, 2016) }\end{array}$ & $\begin{array}{l}\text { Melanjutkan penggunaan } \\
\text { Rekomendasi pada orang lain } \\
\text { Ketahanan untuk tidak } \\
\text { pindah ke bank lain. }\end{array}$ \\
\hline
\end{tabular}

\section{Sumber : Data Olahan (2020)}

\section{HASIL DAN PEMBAHASAN}

Analisis data yang digunakan dalam penelitian ini menggunakan pendekatan Partial Least Square (PLS) persamaan Structural Equation Modeling (SEM) yang berbasis varian. Evaluasi model dalam PLS dilakukan dengan melakukan evaluasi pada outer model dan inner model. Outer model dievaluasi dengan menggunakan beberapa tes yakni convergent validity, discriminant validity, dan composite reliability. Inner model diuji dengan menggunakan coefficient deteminant dan goodness of fit. Berikut pengukuran outer dan inner model dalam penelitian ini:

\section{Pengukuran Outer Model}

Menurut (Abdillah \& Jogiyanto, 2015) mengemukakan bahwa uji validitas seluruh konstruk ditahapan-tahapan awal studi juga dapat dilihat dari nilai outer loading dengan level minimal $\pm 0,30$ dan rule of thumb yang biasanya digunakan untuk membuat pemeriksaan awal dari matrik faktor $\pm 0,30$ dipertimbangkan telah memenuhi level minimal, untuk loading $\pm 0,40$ dianggap lebih baik dan untuk loading 0,50 dianggap signifikan secara praktikal.(Joe F. Hair et al., 2011) mengemukakan bahwa nilai reliabilitas dianggap cukup adalah 0.5 sampai dengan 0.6 dan composite reliability diatas 0.6 dinilai lebih baik dalam mengestimasi konsistensi internal suatu konstruk. (Joseph F. Hair et al., 2019) menyatakan bahwa cronbach alpha masing-masing sub dimensi harus lebih besar daripada 0.7. Hasil perhitungan outer loading, AVE, composite reliability dan cronbachs alpha disajikan dalam tabel 4 berikut: 
Tabel 4. Hasil Perhitungan Outer Loading, AVE, Composite Reliability dan Cronbachs Alpha

\begin{tabular}{|c|c|c|c|c|c|c|}
\hline \multicolumn{3}{|c|}{ Indikator dan Variabel } & \multirow{2}{*}{$\begin{array}{r}\begin{array}{c}\text { Loading } \\
\text { Factor }\end{array} \\
0.793\end{array}$} & \multirow{2}{*}{$\begin{array}{c}\boldsymbol{C R} \\
12.086\end{array}$} & \multirow{2}{*}{$\begin{array}{c}\text { Sig. } \\
0.000\end{array}$} & \multirow{2}{*}{$\begin{array}{r}\begin{array}{c}\text { Rata- } \\
\text { rata }\end{array} \\
3,66\end{array}$} \\
\hline Tangible & <---- & Kualitas Layanan & & & & \\
\hline Responsiveness & $<---$ & Kualitas Layanan & 0.618 & 9.144 & 0.000 & 3,83 \\
\hline Realibility & $<---$ & Kualitas Layanan & 0.767 & 11.315 & 0.000 & 3,74 \\
\hline Assurance & <---- & Kualitas Layanan & 0.810 & 12.570 & 0.000 & 4,09 \\
\hline Emphaty & $<---$ & Kualitas Layanan & 0.804 & Fix & 0.000 & 3,97 \\
\hline Experience & $<---$ & Kepuasan Pelanggan & 0.802 & 8,623 & 0.000 & 3.89 \\
\hline Overall Saticfaction & $\begin{array}{ll}<--- \\
\end{array}$ & Kepuasan Pelanggan & 0.913 & Fix & 0.000 & 3.85 \\
\hline $\begin{array}{l}\text { Pembelian } \\
\text { Ulang }\end{array}$ & $<---$ & Loyalitas & 0.855 & 14.520 & 0.000 & 3,89 \\
\hline $\begin{array}{l}\text { Rekomendasi } \\
\text { kan }\end{array}$ & <---- & Loyalitas & 0.887 & Fix & 0.000 & 3,91 \\
\hline $\begin{array}{l}\text { Ketahanan Tidak } \\
\text { berpindah }\end{array}$ & $<---$ & Loyalitas & 0.795 & 13.507 & 0.000 & 3,86 \\
\hline
\end{tabular}

Sumber : Data Olahan (2020)

Berdasarkan tabel 4 diatas dapat diketahui bahwa semua item yang mengukur kualitas pelayanan, kepuasan pelanggan dan loyalitas pelanggan memiliki factor loading diatas 0.5 dan item-item pertanyaan yang dibawah 0.5 dinyatakan tidak valid atau dihapus. Dengan demikian demikian item-item tersebut dinyatakan valid untuk mengukur variabelnya. Nilai diskriminan reliability (AVE) pada variabel kualitas pelayanan, kepuasan pelanggan dan loyalitas pelanggan, menunjukkan nilai yang lebih besar dari 0.5. Dengan demikian, berdasarkan perhitungan diskriminan reliability (AVE) semua item dinyatakan reliabel dalam mengukur variabel latennya. Nilai composite reliability pada variabel kualitas layanan,, kepuasan pelanggan dan loyalitas pelanggan menunjukkan nilai yang lebih besar dari 0.7. Dengan demikian, berdasarkan perhitungan composite reliability semua item dinyatakan reliabel dalam mengukur variabel latennya. Cronbach's Alpha pada variabel kualitas layanan, kepuasan pelanggan dan loyalitas pelanggan menunjukkan nilai yang lebih besar dari 0.6. Dengan demikian, berdasarkan perhitungan Cronbach's Alpha semua sub variabel dinyatakan reliabel dalam mengukur variabel latennya. Validitas diskriminan dihitung menggunakan cross loading dengan kriteria bahwa apabila nilai loading suatu item dalam suatu variabel yang bersesuaian lebih besar dari nilai loading suatu item pada variabel lainnya maka item tersebut dinyatakan valid dalam mengukur variabel yang bersesuaian.

\section{Pengukuran Inner Model}

Goodness of fit model digunakan untuk mengetahui besarnya kemampuan variabel endogen untuk menjelaskan keragaman variabel eksogen, atau dengan kata lain untuk mengetahui besarnya kontribusi variabel eksogen terhadap variabel endogen. Goodness of fit model dalam analisis PLS dilakukan dengan menggunakan $Q$-Square predictive relevance $(\mathrm{Q} 2)$. Q2 didasarkan pada koefisien determinasi seluruh variabel dependen. Besaran Q2 memiliki nilai dengan rentang $0<\mathrm{Q} 2<1$, sehingga semakin mendekati 1 menunjukkan model yang semakin baik. Adapun hasil 
Goodness of fit model yang telah diringkas dalam tabel berikut:

Tabel 5. Uji Goodness of Fit Model

\begin{tabular}{ll}
\hline Variabel & R2 \\
\hline Kepuasan pelanggan & 0.689 \\
\hline Loyalitas pelanggan & 0.459 \\
\hline $\mathrm{Q} 2=1-(1-\mathrm{R} 12)(1-\mathrm{R} 22)->$ & \\
$\mathrm{Q} 2=1-(1-0.689)(1-0.459)=$ & \\
0.832 & \\
\hline
\end{tabular}

Sumber: Data Olahan (2020)

Q-Square predictive relevance (Q2) bernilai 0.832 atau $83.2 \%$. Hal ini dapat menunjukkan bahwa keragaman variabel loyalitas pelanggan mampu dijelaskan oleh variabel kualitas pelayanan, kepuasan pelanggan. secara keseluruhan sebesar $83.2 \%$, sedangkan sisanya sebesar $16.8 \%$ merupakan kontribusi variabel lain yang tidak dibahas dalam penelitian ini.

\section{Pengujian Hipotesis}

Pengujian terhadap hipotesis dilakukan melalui pengujian koefisien jalur pada model persamaan struktural. Tabel 6 menyajikan hasil uji hipotesis dengan melihat nilai $p$ value. Jika nilai $p$ value lebih kecil dari 0.05 maka hubungan antar variabel signifikan.

Tabel 6. Hasil Pengujian Hipotesis

\begin{tabular}{llccl}
\hline Variabel Independen & Variabel Dependen & $\begin{array}{c}\text { Koefisien } \\
\text { Jalur }\end{array}$ & P-Value & Keterangan \\
\hline Kualitas Layanan & Kepuasan Nasabah & 0,610 & 0,011 & Significant \\
\hline Kualitas Layanan & Loyalitas Pelanggan & 0,334 & 0,000 & Significant \\
\hline Kepuasan Nasabah & Loyalitas Pelanggan & 0,619 & 0,000 & Significant \\
\hline
\end{tabular}

*significant at level 0,05 (two-tiled)

Sumber : Data Olahan (2020)

Pengujian hipotesis H1 sampai H3 dilakukan menggunakan t-test dengan tingkat signifikansi alpha 5\% terhadap regression weight/loading factor/coofisien $\lambda$. Uji ini dilakukan untuk menolak atau menerima $\mathrm{H} 0$, dimana koefisien $\lambda \mathrm{i}=0$ (bobot regresi variabel independen terhadap variabel dependen tidak diterima), dengan demikian: $\mathrm{H} 0: \lambda \mathrm{i}=0$ (tidak diterima) dan $\mathrm{Ha}: \lambda \mathrm{i}>0$ (diterima secara signifikan).

\footnotetext{
Ketentuan uji regression weight dalam SEM, untuk dapat menerima/menolak $\mathrm{H}_{0}$ didasarkan pada perbandingan nilai $t_{\text {hitung }}$ dengan $t_{\text {tabel }}$ dimana $t_{\text {hitung }}$ identik dengan CR (critical ratio) yang diuji dengan nilai probabilitas atau $p$ (Fox, 2006), dengan ketentuan :
}

a. Jika $p<0,05$ maka $\mathrm{H}_{0}$ ditolak, berarti ada pengaruh yang signifikan dari variabel independen terhadap variabel dependen.

b. Jika $p>0,05$ maka $\mathrm{H}_{0}$ diterima, berarti tidak ada pengaruh yang signifikan dari variabel independen terhadap variabel dependen.

Pengujian hipotesis dalam model penelitian ini adalah dengan uji $\mathrm{t}$ dan menggunakan perbandingan nilai critical ratio ( $\mathrm{t}_{\text {hitung }}$ ) dengan tingkat signifikansi $5 \%$ (alpha 0,05 ). $\mathrm{H}_{0}$ diterima jika nilai probabilitas $(p)>0,05$ berarti pengaruh jalur antar konstruk tidak signifikan. $\mathrm{H}_{\mathrm{a}}$ diterima jika $\mathrm{p}<0,05$. 
Tabel 6 diatas menyajikan hasil uji hipotesis dengan melihat nilai $p$ value. Jika nilai $p$ value lebih kecil dari 0.05 maka hubungan antar variabel signifikan.
Model hubungan antar variabel dependen dan variabel independen disajikan pada gambar 2 di bawah ini :

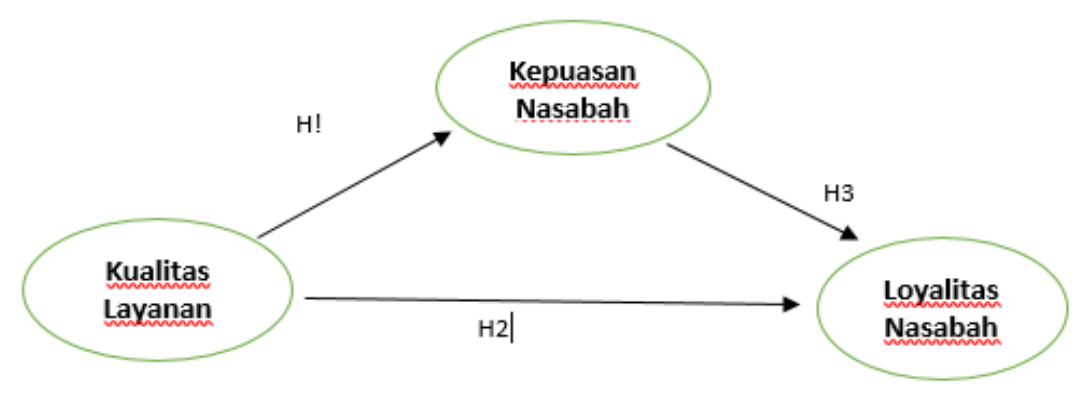

\section{Gambar 2. Model Hubungan Antar Variabel Dependen Dan Variabel Independen}

Pada tabel 4 menunjukkan bahwa nilai critical ratio $(C R)$ pada 3 jalur hubungan memperlihatkan hasil yang lebih besar dari $t_{\text {tabel }}$ yang berarti bahwa antar variabel berpengaruh signifikan sementara satu jalur lainnya menunjukkan nilai $C R$ yang kurang dari $t_{\text {tabel }}$ dan tidak signifikan. Interpretasi dari Tabel 4 dapat dijelaskan sebagai berikut :

Pengujian hipotesis (H1) dengan model persamaan struktural menghasilkan koefisien jalur pengaruh langsung kualitas pelayanan terhadap nilai loyalitas nasabah dengan probabilitas 0,011 (lebih kecil dari nilai alpha 0,05 ) dan nilai critical ratio $\left(\mathrm{t}_{\text {hitung }}=2.534\right)$ serta nilai koefisien standardized sebesar 0.334. Hasil ini memberikan arti bahwa semakin baik kualitas pelayanan akan semakin meningkatkan loyalitas nasabah. Kualitas pelayanan yang baik yang diberikan oleh bank syariah, akan menyebabkan nasabah loyal terhadap bank syariah dan akan menjadikan bank syariah adalah pilihan yang utama.

Berdasarkan hasil analisis diatas dapat diketahui bahwa hipotesis $\mathrm{H} 1$ diterima. Bahwa kualitas pelayanan berpengaruh secara signifikan terhadap kepuasan nasabah. Nasabah yang sudah mendapatkan pelayan. yang baik dan berkualitas dari bank syariah, tentunya akan merasa puas terhadap pelayanan bank syariah. Nasabah yang nerasa puas terhadap bank syariah, akan berbagi rasa dan pengalamanan kepada orang lain dan hal ini akan menjadi referensi yang menguntungkan bagi bank syariah. Kepuasan nasabah (satisfaction) adalah salah satu tujuan yang harus tetap dipertahankan oleh bank syariah untuk menghadapi tantangan yang dinamis dalam bidang jasa perbankan, terutama menghadapi pesaing dengan bank konvensional.

Hasil penelitian ini mendukung pendapat (Atmaja, 2018., Burhanudin, 2018., Suminar, 2017., Tumbuan et al., 2014., Yaqin \& Ilfitriah, 2015) bahwa kualitas jasa (pelayanan) harus dimulai dari kebutuhan pelanggan dan berakhir dengan kepuasan pelanggan, dan hubungan tersebut secara teoritis dan empiris adalah positif. Penelitian ini bertolak belakang dengan penelitian yang dilakukan oleh (Powpaka, 1996) bahwa kualitas pelayanan tidak berpengaruh terhadap kepuasan pelanggan (nasabah).

$\mathrm{H} 2$ diterima. Bahwa kualitas pelayanan berpengaruh secara signifikan 
terhadap loyalitas nasabah. Nasabah yang sudah mendapatkan pelayanan yang baik dan berkualitas dari bank syariah, tentunya akan merasa loyal terhadap bank syariah. Nasabah yang merasa loyal terhadap bank syariah, akan tetap setia kepada bank syariah dan tidak akan berpindah ke bank konvensional, akan menjadikan bank syariah sebagai pilihan utama. Hal ini mendukung penelitian yang dilakukan oleh (Atmaja, 2018., Misbach, 2017., Yaqin \& Ilfitriah, 2015)

Nasabah bank syariah yang loyal akan memberikan informasi yang baik kepada orang tentang pelayanan bank syariah yang tidak kalah dengan bank konvensional. Selain itu juga mempunyai hubungan emosional, bahwa dengan menjadi nasabah bank syariah sudah mendapat pahala karena berdasarkan syariat Islam dan terhindar dari transaksi yang mengandung unsur riba.

H3 diterima, bahwa kepuasan nasabah berpengaruh terhadap loyalitas nasabah. Nasabah bank syariah yang puas akan pelayanan yang diberikan akan dapat mempertahankan loyalitas nasabah terhadap bank syariah dan akan menjadikan bank syariah pilihan utama. Penelitian ini mendukung mendapat (Absah, 2015), bahwa dengan terciptanya kepuasan nasabah yang optimal akan mendorong terciptanya loyalitas dibenak nasabah. Loyalitas nasabah dipandang sebagai kekuatan hubungan antara relatif seseorang dan bisnis berulang. Hal ini berbeda dengan pendapat (Söderlund, 2002), bahwa hubungan kepuasan dengan loyalitas tidak bersifat linear. Sejumlah pelanggan yang mengekspresikan kepuasan masih juga berpindah merek, dan sejumlah pelanggan yang tidak puas justru tidak berpindah merek.

\section{KESIMPULAN}

Layanan bank syariah yang ramah, murah senyum dan berpakaian sopan serta berjilbab membuat nasabah puas dan merasa aman bertransaksi di bank syariah, karena bank syariah mempunyai reputasi dan keamanan yang baik, jujur dalam bertransaksi dan sesuai dengan ajaran syariah Islam. Loyalitas nasabah bank syariah perlu ditingkatkan dengan meningkatkan kualitas pelayanan. Loyalitas dalam hal ini adalah nasabah akan tetap memanfaatkan ulang jasa bank, memberikan informasi kepada orang lain dan akan menjadikan bank syariah sebagai pilihan utama. Nasabah yang puas akan meningkatkan hubungan jangka panjang dengan tetap melanjutkan menjadi nasabah bank syariah dan akan merekomendasikan kepada orang lain. Nasabah yang puas akan menghasilkan loyalitas dan akan tetap setia menjadikan bank syariah sebagai pilihan utama. Hasil penelitian ini mengindikasikan bahwa jasa bank syariah harus lebih meningkatkan kualitas pelayanan sehingga nasabah akan puas dan akan tetap loyal kepada bank syariah dan tidak akan berpindah ke bank konvensional.

\section{DAFTAR PUSTAKA}

Abdillah, W., \& Jogiyanto, H. 2015. Partial Least Square (PLS) Alternatif Structural Equation Modeling (SEM) dalam Penelitian Bisnis. Penerbit Andi. Yogyakarta.

Absah, E. S. R. dan Y. 2015. Analisis Penciptaan Loyalitas Melalui Pengaruh Penerapan Strategi Pemasaran Rasional, Emosional, dan Spiritual Terhadap Kepuasan Nasabah PT. Bank Sumut Syariah Cabang Utama Medan Endang. Jurnal Studi Manajemen Dan Bisnis, 2(1), 63-76.

Abubakar, L., \& Handayani, T. 2018. Percepatan Pertumbuhan Perbankan Syariah Melalui Implementasi Tata Kelola Syariah. Law and Justice, 2(2), 124-134.

Atmaja, J. 2018. Kualitas Pelayanan dan Kepuasan Nasabah Terhadap 
Loyalitas Pada Bank BJB. Jurnal Ecodemica, 2(1), 49-63.

Burhanudin, B. 2018. Pengaruh Harga dan Kualitas Layanan terhadap Kepuasan dan Loyalitas Nasabah pada Bank Sinarmas KK Duri Pulo Gambir Jakarta Pusat. Sosio E-Kons, 10(1), 75-86.

Dewi, S. 2016. Komparasi 5 Metode Algoritme Klasifikasi Data Minig Pada Prediksi Keberhasilan Pemasaran Produk Layanan Perbankan. Techno Nusa Mandiri, 5(3), 545-550.

Fox, J. 2006. Structural equation Modeling with The Sem Package in R. Structural Equation Modeling. A Multidiciplanary Journal, 13(3), 465-486.

Hair, Joe F., Ringle, C. M., \& Sarstedt, M. 2011. PLS-SEM: Indeed a silver bullet. Journal of Marketing Theory and Practice, 19(2), 139-152.

Hair, Joseph F., Risher, J. J., Sarstedt, M., \& Ringle, C. M. 2019. When to use and how to report the results of PLSSEM. In European Business Review, 31(1), 2-24,

Holbrook, M. B. 2012. The Nature of Customer Value: An Axiology of Services in the Consumption Experience. In Service Quality: New Directions in Theory and Practice, 21(1), 21-71.

Indah, D. 2016. Pengaruh E-Banking dan Kualitas Pelayanan terhadap Loyalitas Nasabah pada PT. Bank BNI'46 Cabang Langsa. Jurnal Manajemen Dan Keuangan Unsam, 2(2), 545-554.

Johnson, M. D., Anderson, E. W., \& Fornell, C. 2014. Rational and Adaptive in a Performance Satisfaction Expectations Framework Customer. Journal of Consumer
Research, 2(1), 695-707.

Khan, M., \& Fasih, M. 2014. Impact of service quality on customer satisfaction and customer loyalty: Evidence from banking sector. Pakistan Journal of Commerce and Social Sciences (PJCSS), 8(2), 331354.

Kotler, P. 2012. Kotler On Marketing. In Kotler On Marketing. Free Press. New York.

Leninkumar, V. 2017. The Relationship between Customer Satisfaction and Customer Trust on Customer Loyalty. International Journal of Academic Research in Business and Social Sciences, 7(4), 450-465.

Misbach, I. 2017. Pengaruh Islamic Bank Service Quality Terhadap Kepuasan Dan Kepercayaan Nasabah Bank Umum Syariah. Telaah Ekonomi Dan Bisnis Islam, 1(1), 55-77.

Moha, S., \& Loindong, S. 2016. The Analysis Of Service Quality On Customer Satisfication And Facilities In Hotel Yuta Manado. Emba, 4(1), 575-584.

Ngo, M. V., \& Nguyen, H. H. 2016. The Relationship between Service Quality, Customer Satisfaction and Customer Loyalty: An Investigation in Vietnamese Retail Banking Sector. Journal of Competitiveness, 8(2), 103-116.

Oliver, R. L. 1997. Satisfaction: A Behavioral Perspective on the Consumer. In McGraw-Hill series. Boston.

Parasuraman, A., Zeithaml, V. A., \& Berry, L. L. 1985. A Conceptual Model of Service Quality and Its Implications for Future Research. Journal of Marketing, 4(4), 41-50.

Powpaka, S. 1999. The role Of Outcome Quality As A Determinant Of 
Overall Service Quality in Different Categories of Services Industries: An Empirical Investigation. Journal of Services Marketing, 10(2), 5-25.

Semuel, H. 2012. Customer Relationship Marketing Pengaruhnya Terhadap Kepercayaan Dan Loyalitas Perbankan Nasional. Jurnal Manajemen Pemasaran, 7(1), 33-41.

Siddiqi, K. O. 2011. Interrelations between Service Quality Attributes, Customer Satisfaction and Customer Loyalty in the Retail Banking Sector in Bangladesh. International Journal of Business and Management, 6(3), 12-36.

Sigit, K. N., \& Soliha, E. 2017. Kualitas Produk Dan Kualitas Layanan Terhadap Kepuasan Dan Loyalitas Nasabah. Jurnal Keuangan Dan Perbankan, 21(1), 157-168.

Söderlund, M. 2002. Customer Familiarity and Its Effects on Satisfaction and Behavioral Intentions. Psychology and Marketing, 19(10), 861-879.

Suminar, R. 2017. Pengaruh Kualitas Layanan Terhadap Kepuasan Konsumen Hypermarket. Jurnal Sekretari Universitas Lampung, 4(1), 1-17.

Sutisna, A. J. 2016. Pengaruh kualitas Pelayanan Terhadap Loyalitas Nasabah pada Kantor AJB bumiputera Syariah Cabang Serang. Jurnal Ilmiah Revenue, 2(2), 128138.

Syukron, A. 2013. Dinamika Perkembangan Perbankan Syariah Di Indonesia. Jurnal Ekonomi Dan Hukum Islam, 3(2), 28-53.

Tjiptono, F., \& Chandra, G. 2011. Service, Quality \& Satisfaction. In Edisi 4. Andi. Yogyakarta.

Tumbuan, W., Kawet, L., \& Pontoh, M.
2014. Kualitas Layanan, Citra Perusahaan Dan Kepercayaan Pengaruhnya Terhadap Kepuasan Nasabah Bank Bri Cabang Manado. Jurnal Riset Ekonomi, Manajemen, Bisnis Dan Akuntansi, 2(3), 285-297.

Yaqin, A., \& Ilfitriah, A. M. 2015. Pengaruh Kualitas Pelayanan Terhadap Kepuasan Dan Loyalitas Nasabah Bank Pengguna E-Banking Di Surabaya. Journal of Business and Banking, 4(2), 245 - 260. 